\title{
Analisis Penyelenggaraan Pendidikan dan Pelatihan Teknis Pelayanan Publik di Pemerintah Kabupaten Simalungun
}

\author{
Natalia Suryani Purba ${ }^{1}$ \\ ${ }^{1}$ Program Magister Administrasi Publik, Sekolah Pascasarjana, Universitas \\ Diponegoro Semarang, purbaliasuryani8@gmail.com
}

\begin{abstract}
Abstrak
Peningkatan kualitas dan keprofesionalan aparatur pemerintah adalah salah satu strategi dalam menciptakan pelayanan publik yang baik. Aparatur pemerintah yang berkualitas dan professional dapat diindikasikan dari sikap dan perilakunya yang penuh dengan kesetiaan dan ketaatan kepada Negara, bermoral, bermental baik, professional, sadar akan tanggung jawab sebagai pelayan publik serta mampu menjadi perekat persatuan dan kesatuan bangsa. Untuk dapat membentuk sosok aparatur tersebut perlu dilaksanakan pembinaan antara lain melalui jalur Pendidikan dan Pelatihan (Diklat) yang mengarah pada upaya peningkatan sikap dan semangat pengabdian yang berorientasi pada kepentingan masyarakat, bangsa, negara, dan tanah air, kompetensi teknis, manajerial dan atau kepemimpinannya. Tujuan dalam penelitian ini adalah untuk mengetahui proses penyelenggaraan pendidikan dan pelatihan teknis di Pemerintah Kabupaten Simalungun dan kendala/hambatan yang dihadapi dalam proses penyelenggaraan diklat tersebut. Metode pendekatan yang digunakan dalam penelitian ini adalah penelitian deskriptif dengan pendekatan kualitatif. Berdasarkan hasil penelitian menunjukkan bahwa penyelenggaraan pendidikan dan pelatihan teknis di Pemerintah Kabupaten Simalungun belum berjalan dengan baik. Beberapa kendala yang terjadi yakni mengenai minimnya penyelenggara yang berkompeten dibidang pendidikan dan pelatihan teknis, serta sarana dan prasarana yang belum memadai.
\end{abstract}

Kata kunci : Aparatur Pemerintah, Pendidikan dan Pelatihan, Teknis.

\begin{abstract}
Improving the quality and professionalism of government officials is one strategy in creating good public service. Quality and professional government apparatus can be indicated by their attitude and behavior that is full of loyalty and obedience to the state, has a moral character, has a good mentality, is professional, is aware of their responsibility as public servants and is able to glue the unity and integrity of the nation. To be able to form the figure of this apparatus, it is necessary to carry out guidance, among others, through the path of education and training which leads to efforts to increase attitudes and a spirit of service oriented towards the interests of the community, nation, state and homeland, technical, managerial or leadership competence. The purpose of this research is to determine the process of implementing education and technical training in the Simalungun district government and the obstacles/obstacles faced in the process of organizing the training. The approach method used in this research with a qualitative approach. Based on the research result, it shows that the implementation of technical education and training in the Simalungun district government has not been going well. Some of the obstacles that occur are the lack of competent administrator in the field of technical education and training, as well as inadequate facilities and infrastructure.
\end{abstract}

Keywords : Education and Training, Government Apparatus, Technique 


\section{Pendahuluan}

Pendidikan dan pelatihan Jabatan Pegawai Negeri Sipil mengarah kepada peningkatan kualitas aparatur sipil negara yang professional untuk menciptakan pelayanan publik yang baik kepada masyarakat sebagaimana disebutkan dalam Peraturan Pemerintah No. 101 Tahun 2000 Tentang Pendidikan dan Pelatihan Jabatan Pegawai Negeri Sipil terkait tujuan dan sasaran diklat yaitu a) Meningkatkan pengetahuan, keahlian, keterampilan dan sikap untuk dapat melaksanakan tugas jabatan secara professional dengan dilandasi kepribadian dan etika PNS sesuai dengan kebutuhan instansi; b) Menciptakan aparatur yang mampu berperan sebagai pembaharu dan perekat persatuan dan kesatuan bangsa; c) Memantapkan sikap dan semangat pengabdian yang berorientasi kepada pelayanan, pengayoman, dan pemberdayaan masyarakat; d) Menciptakan kesamaan visi dan dinamika pola pikir dalam melaksanakan tugas pemerintahan umum dan pembangunan demi terwujudnya pemerintahan yang baik.

Terwujudnya PNS yang memiliki kompetensi yang sesuai dengan persyaratan jabatan masing-masing merupakan sasaran diklat yang hendak dicapai. dengan meningkatnya kualitas dan keprofesionalan aparatur pemerintah diharapkan dapat menciptakan pelayanan publik yang baik serta prima kepada masyarakat. Sebab dewasa ini, keluhan-keluhan yang datang dari masyarakat yang menilai pelayanan publik yang diberikan kepada mereka terkendala akibat masih belum tingginya sikap atau perilaku sumber daya manusia aparatur yang berlangsung berhadapan dengan masyarakat. Tidak dipungkiri juga hadir berbagai kritikan seperti mengapa para pegawai yang telah mengikuti diklat hampir tidak kelihatan perbedaannya dengan setelah mengikuti diklat. Perbedaan yang dimaksud dalam kritik ini adalah perbedaan sikap sebelum dan sesudah mengikuti diklat. Masih nampak aparatur yang sebelum diklat dikategorikan sering terlambat masuk kantor, setelah mengikuti diklatpun belum merubah kebiasaannya tersebut. Masih terdapat peserta diklat memandang bahwa pengiriman mereka sebagai peserta hanya sekedar tugas. Pada sisi ini, ada persepektif bahwa peserta tidak sepenuh hati mengikuti kegiatan sehingga hasil akhirnya hanyalah mendapatkan selembar kertas kualifikasi tertentu dengan kompetensi yang nihil. 
Rendahnya tingkat kualitas sumber daya manusia aparatur dan keprofesionalan pegawai saat ini juga mengakibatkan sering terjadinya diskriminasi dalam penyelenggaraan pelayanan publik. Sebagian besar masyarakat ada yang menerima pelayanan itu dengan maksimal akan tetapi sebagian lagi hanya mendapatkan pelayanan yang sekedarnya karena itulah peningkatan sumber daya manusia dan keprofesionalan pegawai menjadi suatu aspek yang patut diperhatikan dalam upaya peningkatan pelayanan publik. Kondisi birokrat yang memiliki kecakapan, ketrampilan, perilaku yang patuh pada hukum dan peraturan yang berlaku, serta penempatan posisi yang sesuai dengan bidangnya, tentunya akan memberikan dampak yang positif kepada terciptanya pelayanan publik yang berkualitas. Pelayanan publik diharapkan memberikan nuansa demokratis dan berkualitas dan jauh dari kesan diskriminatif (Jannah \& Saidin, 2020).

Proses penyelenggaraan pendidikan dan pelatihan teknis bagi Aparatur Sipil Negara sangat penting untuk mengetahui sejauh mana Aparatur Sipil Negara memahami proses diklat yang dilakukan dan apa saja kendala yang dihadapi baik saat mengikuti diklat dan dalam penerapannya di lingkungan kerja. Pendidikan dan pelatihan adalah suatu proses yang menghasilkan suatu perubahan perilaku sasaran diklat secara konkret. Secara konkret perubahan perilaku itu berbentuk peningkatan kemampuan dari sasaran diklat (Notoadmodjo, 2009). Jika dilihat dari pendekatan system, proses pendidikan dan pelatihan terdiri dari Input (yang diberikan),yaitu materi-materi atau metode belajar dalam diklat yang akan diberikan pada saat proses pendidikan dan pelatihan kepada peserta, dan Output (yang dikeluarkan), yaitu perubahan perilaku atau kemampuan peserta setelah mengikuti pendidikan dan pelatihan.

Pelayanan yang berkualitas sangat tergantung pada berbagai aspek, yaitu bagaimana pola penyelenggaraannya (tata laksana), dukungan sumberdaya manusia, dan kelembagaan. Dilihat dari sisi pola penyelenggaraannya, pelayanan publik masih memiliki berbagai kelemahan antara lain: kurang responsif, kurang informatif, kurang accessible, kurang koordinasi, kurang birokratis, kurang mau mendengar keluhan/saran/aspirasi masyarakat, dan inefisien (Hardiyansyah, 2011). 
Padahal esensi pelayanan publik yaitu memberikan kepuasan kepada masyarakat sebagai pengguna layanan (Anda.,Hussain \& Jopang, 2020)

Pada tahun 2018 berdasarkan Survei Penyelenggaraan Pelayanan Publik Tahun 2018 Ombudsman Republik Indonesia. Predikat kepatuhan pelayanan publik terhadap standar pelayanan publik Kabupaten Simalungun mendapatkan rapor merah (hasil rendah) dengan nilai 11.62, dan jika ingin memperbaiki kualitas pelayanannya harus memenuhi 8 variabel penilaian standar pelayanan publik yang sesuai dengan Undang-Undang, diantaranya standar pelayanan, maklumat pelayanan, sistem informasi pelayanan publik, sarana dan prasarana fasilitas, pelayanan khusus, pengelolaan pengaduan, penilaian kinerja, visi misi dan motto pelayanan, serta atribut pelayanan terpadu.

Ombudsman menetapkan Pemkab Simalungun pada daftar pemerintah daerah yang memiliki rapor merah nomor dua setelah Tanjung Balai alias buruk tentang penyelenggaraan pelayanan publik tahun 2018. Berdasarkan survei ini, Pemkab Simalungun hanya memperoleh poin 11.62. pada tahun 2018, terdapat 13 pemerintah kabupaten dan kota di Sumut yang disurvei Ombudsman Perwakilan Sumut. Ke-13 pemerintah daerah ini dipilih lantaran rapor penyelenggaraan pelayanan publik ditahun sebelumnya dikategorikan belum baik. Sementara untuk pemerintah daerah yang sudah masuk zona hijau, tidak lagi disurvei.

Predikat penyelenggaraan pelayanan publik yang buruk atau zona merah disematkan kepada Pemkab Simalungun beserta enam pemerintah daerah lainnya, yakni Pemkab Karo (36.97), Pemkab Labuhan batu (35.64), Pemkab Nias Selatan (14.66), Pemkab Simalungun (11.62), Pemko Tebingtinggi (48.98), Pemkab Padang Sidempuan(16.66) dan Pemko Kota Tanjungbalai (10.02). Kemudian daftar pemerintah daerah yang masuk zona kuning adalah Pemkab Toba Samosir (63.14), Pemkab Pakpak Bharat (54.03), Pemko Binjai (75.77) dan Pemko Pematangsiantar (58.39) sedangkan pemerintah daerah yang dinobatkan memiliki raport bagus alias zona hijau adalah Pemkab Langkat (96.53) dan Pemkab Serdang Bedagai (89.59).

Berdasarkan permasalahan di atas penelitian ini bertujuan untuk menganalisa penyelenggaraan Pendidikan dan Pelatihan Teknis Pelayanan Publik di Pemerintah Kabupaten Simalungun, serta kendala yang dihadapi dalam 
Penyelenggaraan Diklat Teknis Pelayanan Publik di Pemerintah Kabupaten Simalungun.

\section{Metode}

Jenis penelitian yang digunakan dalam riset ini adalah penelitian deskriptif dengan pendekatan kualitatif. Bogdan dan Taylor dalam Moleong (2014) menekankan bahwa penelitian deskriptif, yaitu penelitian yang bertujuan untuk mendeskripsikan hasil penelitian baik berupa kata-kata tertulis atau lisan dari orang-orang dan perilaku yang dapat diamati. Penggunaan desain penelitian deskriptif kualitatif dalam penelitian ini digunakan untuk menganalisis Penyelenggaraan Diklat Teknis Pelayanan Publik Bagi Aparatur Sipil Negara (ASN) dan kendala yang dihadapi dalam Penyelenggaraan Diklat Teknis Pelayanan Publik di Pemerintah Kabupaten Simalungun.

Adapun Sumber data yang digunakan dalam penelitian ini adalah sumber data primer dan sumber data sekunder. Dalam penelitian ini, data primer didapatkan melalui wawancara mendalam dengan informan penelitian untuk mendapatkan informasi mengenai Penyelenggaraan Diklat Bagi Aparatur Sipil Negara (ASN) di Pemerintah Kabupaten Simalungun. Informan peneliti dalam penelitian ini yakni Kepala Badan Kepegawaian Pemkab Simalungun. Selain itu, peneliti juga menggunakan data hasil observasi lapangan yakni berupa pengamatan peneliti pada penyelenggaraan Diklat Bagi Aparatur Sipil Negara (ASN) di Pemkab Simalungun. Sedangkan data sekunder yang digunakan dalam penelitian ini berupa dokumendokumen, arsip-arsip resmi yang diperoleh dari Badan Kepegawaian Daerah Pemkab Simalungun atau instansi terkait.

\section{Hasil dan Pembahasan}

\section{Penyelenggaraan Pendidikan dan Pelatihan Teknis di BKPPD Kabupaten Simalungun}

Program pendidikan dan pelatihan atau biasanya disebut program diklat merupakan pengembangan sumber daya manusia aparatur berbasis kompetensi yang mempunyai peran yang cukup strategis dalam meningkatkan sumber daya 
manusia aparatur sehingga diharapkan menjungjung tinggi profesionalisme baik memiliki kompetensi serta sikap dan perilaku sesuai dengan tugas dan peran yang dijalankan.

Badan Kepegawaian, Pendidikan dan Pelatihan daerah Pemerintah Kabupaten Simalungun ialah instansi pemerintah yang berfungsi sebagai tempat penyelenggaraan diklat dan instansi pemerintah yang mengelola pengadaan diklat dari awal perencanaan hingga evaluasi yang dilakukan pada peserta diklat. Proses penyelenggaraan diklat membutuhkan persiapan yang matang dari segi administrasi dan segi akademis agar tujuan dan sasaran penyelenggaraan diklat dapat tercapai yaitu untuk meningkatkan kemampuan dan kompetensi serta pemberian motivasi dalam berorganisasi dalam hal ini perannya sebagai pemegang jabatan pada instansi pemerintah.

Jumlah masyarakat yang besar dan wilayah yang luas di Kabupaten Simalungun membutuhkan pelayan publik yang berkualitas dan prima demi terwujudnya pemerintahan yang baik dan lancar. Oleh karena itu, dibutuhkan pendidikan dan pelatihan yang berkesinambungan bagi pegawai dalam menjalankan tugas dan fungsinya.

Dalam penelitian ini, pendekatan yang digunakan untuk mengukur dan menganalisis Penyelenggaraan Pendidikan dan Pelatihan Teknis di Pemerintah Kabupaten Simalungun menggunakan indikator Barry (dalam Umar, 1999) yaitu reaksi (reaction), pembelajaran (learning), perilaku (behavior) dan hasil (result). Faktor-faktor tersebut tidak hanya berdiri sendiri namun juga saling memiliki keterkaitan, faktor-faktor tersebut akan dijelaskan sebagai berikut:

\section{a. Reaksi (reaction)}

Reaksi adalah respon yang diberikan peserta yang mengikuti penyelenggaraan diklat teknis. Indikator reaksi dalam penyelenggaraan diklat terdiri dari pelayanan panitia penyelenggara dan kualitas instruktur, kurikulum materi pelatihan, metode belajar, sarana prasarana, dan kebermaknaan isi diklat.

Pihak panitia penyelenggara pendidikan dan pelatihan diklat di Pemerintah Kabupaten Simalungun yang berkompeten dalam bidang pendidikan dan pelatihan masih terbilang minim sehingga setiap dilaksanakannya penyelenggaraan diklat 
membutuhkan pihak-pihak yang berperan langsung membantu kesiapan diklat selama proses kegiatan berlangsung. Hal tersebut diharapakan dapat memperlancar kegiatan diklat agar tujuan dan sasaran diklat tercapai.

\section{b. Pembelajaran (Learning)}

Belajar dapat didefenisikan sebagai perubahan sikap mental (attitude), perbaikan pengetahuan serta penambahan keterampilan peserta setelah selesai mengikuti program diklat. Materi pembelajaran harus disesuaikan dengan sasaran diklat yang ingin dicapai baik dengan menggunakan cara atau metode tertentu agar peserta diklat dapat memahami dengan mudah isi dari materi yang disampaikan.

Proses pembelajaran yang diikuti oleh peserta pendidikan dan pelatihan teknis di Pemerintah Simalungun baik dengan menggunakan metode pembelajaran berupa diskusi, Tanya jawab, simulasi, debat dan studi kasus yang disesuaikan dengan kebutuhan organisasi perangkat daerah cukup baik, hal ini dapat berjalan dengan baik karena sebelum penyelenggaraan diklat telah disusun perencanaan diklat baik kesiapan peserta (menyiapkan mental dan fisik) diklat, serta literature terkait materi.

\section{c. Perilaku (Behavior)}

Proses penyelenggaraan pendidikan dan pelatihan dikatakan berhasil bila perilaku dari peserta diklat menunjukkan perubahan yang signifikan setelah kembali ke lingkungan kerjanya, baik perubahan sikap mental (attitude) dan perilaku di lingkungan kerja yang sesuai dengan sasaran diklat untuk meningkatkan keterampilan dan kompetensi pegawai sebagai peserta diklat. Perilaku kerja pegawai yang mengikuti diklat teknis di Lingkungan Pemerintah Kabupaten Simalungun menunjukkan perubahan sikap ke arah yang lebih baik serta peningkatan pengetahuan dan keterampilan pegawai di lingkungan kerjanya.

\section{d. Hasil (result)}

Hasil yang diharapkan dari terselenggaranya pelaksanaan diklat harus sesuai dengan tujuan dan sasaran diklat yaitu untuk meningkatkan kompetensi dan keterampilan peserta diklat. Penyelenggaraan diklat dikatakan berhasil bila peserta diklat dapat memahami isi dari materi diklat yang di sampaikan selama proses diklat 
berlangsung dan menunjukkan perubahan sikap yang signifikan setelah mengikuti diklat.

Indikator yang digunakan dalam Penyelenggaraan Diklat Teknis di Pemerintah Kabupaten Simalungun yang meliputi Reaksi (reaction), Pembelajaran (learning), Perilaku (behavior) dan Hasil (result), jika dilihat dari indikator penyelenggaraan diklat di Pemerintah Kabupaten Simalungun bisa dikatakan belum berjalan dengan baik masih ada satu indikator yang belum memadai, yakni reaksi (reaction); yaitu pelayanan pihak penyelenggara dan kualitas instruktur; masih terbilang minim, pegawai yang memiliki kompetensi di bidang diklat masih minim sehingga membutuhkan pihak lain yang berperan dalam penyelenggaraan diklat. Sarana dan prasarana yang mendukung terselenggaranya diklat belum memadai sehingga setiap penyelenggaraan diklat selalu memanfaatkan fasilitas lain seperti hotel.

\section{Kendala dalam Proses Penyelenggaraan Pendidikan dan Pelatihan Teknis di BKPPD Kabupaten Simalungun}

Terkait kendala dalam proses penyelenggaraan diklat, kendala yang terjadi dalam penyelenggaraan pendidikan dan pelatihan teknis di Pemerintah Kabupaten Simalungun berasal dari aspek internal itu sendiri, yaitu: Pertama, Masih minimnya pegawai yang berkompeten dibidang diklat sebagai pihak penyelenggara di Badan pendidikan dan Pelatihan Pemerintah Kabupaten Simalungun. Kedua, Sarana dan prasarana sebagai faktor pendukung terlaksananya program pendidikan dan pelatihan teknis belum memadai.

\section{Kesimpulan}

Berdasarkan hasil penelitian menunjukkan bahwa penyelenggaraan pendidikan dan pelatihan teknis di Pemerintah Kabupaten Simalungun belum berjalan dengan baik karena masih ada kendala dalam penyelenggaraan pendidikan dan pelatihan teknis. Selain itu, beberapa kendala yang terjadi yakni mengenai minimnya penyelenggara yang berkompeten dibidang pendidikan dan pelatihan teknis, sarana dan prasarana yang belum memadai untuk terselenggaranya 
pendidikan dan pelatihan sehingga setiap diadakannya diklat harus menggunakan fasilitas lain seperti hotel. Hal ini mengandung implikasi bahwa perlu dilakukan perbaikan, baik dengan meningkatkan kompetensi pegawai dibidang diklat dan melengkapi sarana dan prasarana yang mendukung terlaksananya penyelenggaraan pendidikan dan pelatihan teknis.

Berdasarkan kesimpulan dan implikasi diatas, berikut ini peneliti memberikan saran yang diharapkan dapat menjadi masukan untuk penyelenggaraan pendidikan dan pelatihan teknis di Pemerintah Kabuapten Simalungun yakni pada indikator reaksi (reaction); meningkatkan kompetensi pegawai yang memahami di bidang pendidikan dan pelatihan teknis sebagai panitia penyelenggara, mengadakan trainer of fasilitator dan manajemen of trainer bagi pegawai diklat sehingga setiap diadakannya penyelenggaraan diklat dapat berjalan dengan baik dan lancar; mengusulkan kepada pimpinan supaya membangun sarana dan prasarana yang mendukung terselenggaranya pendidikan dan pelatihan di Pemerintah Kabupaten Simalungun

\section{Referensi}

Anda, A. R., Hussain, M. N., \& Jopang, J. (2020). Penerapan Fungsi Manajemen Pemerintahan dalam Pelayanan Publik di Kantor Dinas Kependudukan dan Pencatatan Sipil Kabupaten Wakatobi. NeoRespublica: Jurnal Ilmu Pemerintahan, 1(2), 150-166.

Hardiansyah. (2011). Kualitas Pelayanan Publik. Yogyakarta: Gava Media Husein Umar. (1999). Riset Sumber Daya Manusia dalam Organisasi. Jakarta: PT Gramedia Pustaka Utama

J.Moleong, Lexy. (2014). Metode Penelitian Kualitatif. Edisi Revisi. Bandung: PT Remaja Rosda karya

Jannah, M., \& Saidin, S. (2020). Efektifitas Komunikasi Pemerintahan dalam Pelayananan Publik Pada Kantor Pertanahan Nasional Kota Kendari. NeoRespublica: Jurnal Ilmu Pemerintahan, 1(2), 86-101.

Notoatmodjo, Soekidjo. (2009). Pengembangan Sumber Daya Manusia. Jakarta: Rineka Cipta 
Presiden Republik Indonesia. (2002). Peraturan Pemerintah Nomor 101 Tahun 2000 Tentang Pendidikan dan Pelatihan Jabatan Pegawai Negeri Sipil, pada Jaringan Dokumentasi dan Informasi Hukum (JDIH) Badan Pemeriksa Keuangan (BPK) RI website: https://peraturan.bpk.go.id/Home/Details/53673/pp-no-101-tahun2000

OMBUDSMAN Republik Indonesia, (2018), Survey Ombudsman, 7 Daerah Masuk Zona Merah Di Sumut, diakses 18 April 2019 pada https://ombudsman.go.id/perwakilan/news/r/pwk--surveyombudsman-7-daerah-masuk-zona-merah-di-sumut 